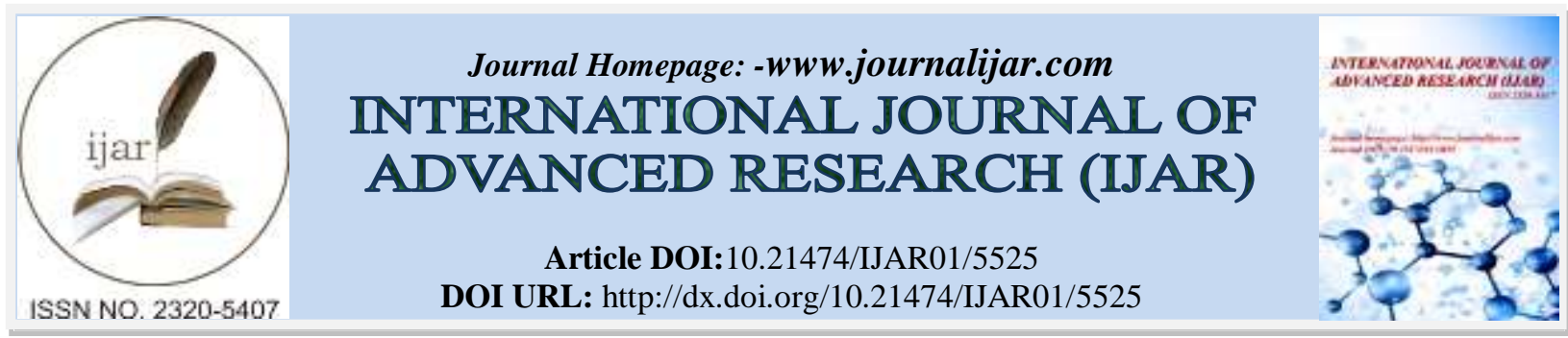

RESEARCH ARTICLE

\title{
THE EFFECT OF TIERED TRAINING ON PEDAGOGICAL KNOWLEDGE OF EARLY CHILDHOOD TEACHER IN PROVINCE OF NORTH MALUKU.
}

Rosita Wondal and Farida Samad.

\section{Manuscript Info}

..........................

Manuscript History

Received: 03 August 2017

Final Accepted: 05 September 2017

Published: October 2017

Key words:-

Tiered Training, Pedagogical

Knowledge

\section{Abstract}

The aim of this study is to determine the effect of tiered training on pedagogical knowledge of early childhood teachers in the province of North Maluku. This research uses ex post facto research method with Anava and the sample in this research is 90 teachers who follow the advanced, basic and other training in North Maluku province. The result of the research shows that: There is effect of pedagogic education to pedagogic teacher of early childhood teacher, pedagogic knowledge of teacher following advanced training is higher than basic training and other training. The conclusion is that tiered training can improve pedagogical knowledge of early childhood teachers.

Copy Right, IJAR, 2017,. All rights reserved.

\section{Introduction:-}

Life quality in a nation is determined by the quality of education. To guarantee the quality of education, it is needed a reliable educator or teacher proven by competence skills. One of the components of education which is very important in order to implement the strategic plan is the teacher. Teachers are one of the most crucial components of education in shaping the face of education in Indonesia.

Based on data from the Teacher Competency Test in 2015, it showed that North Maluku Province was ranked the last of 34 provinces in Indonesia, with an average score of 41.96 with a minimum competency standard of 55 . The average competence test scores especially for early childhood teachers for pedagogic competence is 43.36 with highest score 71.43 and lowest 11.91 while for professional competence average score 52.12 with highest score 76.53 and lowest score is 22.11 . Based on these results, it can be seen that the quality of teachers in this case is very diverse in each region especially in Indonesia (Data of Directorate General Teachers and Educational Staff of Ministry of Education and Culture Republic of Indonesia, 2015).

Pedagogical knowledge according to Kaiser (2005: 1) is a knowledge that focuses on learning about teaching techniques. The same opinion is also expressed by Gurung and Schwartz (2009: 1) that pedagogic is related to how we assess the teaching and learning process and how teaching and learning can be improved.

Cochran et al, defines pedagogical knowledge as follows: "The transformation of subject matter, analogues, metaphors, examples, problems, demonstrations, and classroom activities; adapts the material to students, abilities, gender, prior knowledge, and preconceptions (those pre-instructional informal, or nontraditional ideas students bring to the learning setting); and finally tailors the material to be taught (http://en.wikipedia.org/wiki/LeeShulman, accessed on January 2017). 
One way from outside of teacher's self who can help improve pedagogic knowledge is through training activities. Wexley and Yuki (1977: 301) said that training is the process by which employees learn the knowledge, skills, attitudes, and behaviors necessary to carry out the work effectively. Moreover, Hargreaves (2000: 4) reveals that training on governance is effectively responsible for providing labor to improve skills and knowledge, to promote employee creativity and to assist employees toward achieving common goals.

The Indonesian government has endeavored in various ways to improve teacher pedagogic compliance. The policy of increasing the competence through the stratified training for early childhood teachers as stated in Permendiknas Number 36 Year 2010 concerning the organization and working procedures of the Ministry of National Education and the strategies described in the Annex of Permendiknas Number 2 Year 2010 on the strategic plan of the Ministry of National Education Year 2010-2014 in the form of strategic plan Main Unit namely Strategic Plan (Renstra) of Directorate of PPTK PAUDNI. In the strategic plan, it is explained that the improvement of the competence of early childhood teacher is done through tiered training to technical training and functional training. The goal to be achieved from the implementation of early childhood education tiered training is to improve the competence of early childhood teachers (caregivers, companion teachers, and teachers) in accordance with the competence standard requirements. The expected outcome is the availability of competent early childhood educators so as to provide maximum early childhood services (htpp://forumpendidikkristen.files.wordhress.com/2014/03/kebijakanpembinaan-ptk-paud-melalui-diklat-berjenjang.hdf. Accessed on November 5, 2016).

Based on the problems that have been proposed, then the research problem is formulated as follows: Is there any effect of tiered training on pedagogic knowledge of early childhood education teachers?

\section{Research Method:-}

The method used in this research is ex post facto research method. Kerlinger (1973: 373) explains that ex post facto research is a comparative causal research that is a systematic empirical research in which the researcher does not control the independent variables directly because the existence of the variables has occurred. The design used is the design of treatment Anova one-way. The installation of variables mentioned above, can be seen in the research design as in table 1 below.

Table 1:-Research Design with Anova one-way.

\begin{tabular}{|c|c|c|c|c|}
\hline Group & I & II & III & $\sum$ \\
\hline N & 20 & 20 & 20 & 60 \\
\hline
\end{tabular}

This research is conducted by simple random sampling technique. The sample consists of 3 groups with the provision of teachers of early childhood education who have the academic qualification of diploma two (D2) in kindergarten education who have attended the basic education training and the follow-up training and also have joined other early childhood training held by the local education office or association of early childhood education teachers with a total of 90 teachers (30 teachers of basic training, 30 teachers of follow-up training and 30 teachers attending other training) in Ternate City and West Halmahera Regency in North Maluku Province. Instrument in this research is test of teacher pedagogic knowledge and self-regulated learning (SRL) questionnaire which has passed validity test by 6 experts in education and psychology and validity and reliability test in the field by 30 early childhood education teachers who are not sample of study but including in the population of North Maluku Province and early childhood education teachers in Tidore city.

\section{Research Findings:}

In general, the description of data on pedagogic knowledge is the result of mastery of knowledge on the output of the training after the teachers do the learning process on the three types of training that is advanced training, basic training and other training. 
Table 2:-Data Group Statistical Description

\begin{tabular}{|c|c|c|c|c|c|c|c|c|}
\hline $\mathrm{Y}$ & \multicolumn{2}{|c|}{$\begin{array}{c}\mathrm{X} 1 \\
\text { (Advanced) }\end{array}$} & \multicolumn{2}{|c|}{$\begin{array}{c}\mathrm{X} 2 \\
\text { (Basic) }\end{array}$} & \multicolumn{2}{|c|}{$\begin{array}{c}\mathrm{X} 3 \\
\text { (Other) }\end{array}$} & \multicolumn{2}{|c|}{$\Sigma \mathrm{B}$} \\
\hline \multirow[t]{6}{*}{$\Sigma \mathrm{A}$} & $\mathrm{n}_{01}=$ & 20 & $\mathrm{n}_{02}=$ & 20 & $\mathrm{n}_{03}=$ & 20 & $\mathrm{n}_{00}=$ & 60 \\
\hline & $\Sigma Y_{01}=$ & 713 & $\Sigma Y_{02}=$ & 662 & $\Sigma Y_{03}=$ & 606 & $\Sigma Y_{00}=$ & 1,981 \\
\hline & $\overline{\mathrm{Y}}_{01}=$ & 35.65 & $\bar{Y}_{02}=$ & 33.10 & $\bar{Y}_{03}=$ & 30.30 & $\bar{Y}_{00}=$ & 33.02 \\
\hline & $\sigma_{01}=$ & 7.90 & $\sigma_{02}=$ & 4.19 & $\sigma_{03}=$ & 5.66 & $\sigma_{00}=$ & 6.40 \\
\hline & $\sigma_{01}^{2}=$ & 62.45 & $\sigma_{02}^{2}=$ & 17.57 & $\sigma_{03}^{2}=$ & 32.01 & $\sigma_{00}{ }^{2}=$ & 40.93 \\
\hline & $\Sigma Y_{01}{ }^{2}=$ & 26,605 & $\Sigma Y_{02}{ }^{2}=$ & 22,246 & $\Sigma Y_{03}{ }^{2}=$ & 18,970 & $\Sigma Y_{00}^{2}=$ & 67,821 \\
\hline
\end{tabular}

\section{Annotation:-}

$\mathrm{X}_{1}$ : Group of teachers who follow advanced training

$\mathrm{X}_{2}$ : Group of teachers who follow basic training

$\mathrm{X}_{3}$ :Group of teachers who follow other training

$\mathrm{n} \quad$ : Amount of samples

$\overline{\mathrm{Y}}$ : Average result score of pedagogic knowledge

$\sigma \quad:$ Standard Deviation

$\sigma^{2}:$ Variance

The research hypothesis was tested by using variance analysis (ANAVA) one-way. Before tested with ANAVA, first tested ANAVA requirement that is normality test and homogeneity test of variance to data that have been obtained. Normality test was conducted to find out whether the study sample came from normal distributed population data, while homogeneity test was done to find out whether the sample came from homogeneous population.

Table 3:-Results of Anava AnalysisDependent Variable: Y

\begin{tabular}{|l|r|r|r|r|r|r|}
\hline Source & $\begin{array}{c}\text { Type III Sum } \\
\text { of Squares }\end{array}$ & \multicolumn{1}{|c|}{ df } & Mean Square & F & $\begin{array}{c}\text { Sig. } \\
\text { Partial Eta } \\
\text { Squared }\end{array}$ \\
\hline Corrected Model & $286.433^{\mathrm{a}}$ & 2 & 143.217 & 3.835 & .027 & .119 \\
\hline Intercept & 65406.017 & 1 & 65406.017 & 1751.494 & .000 & .968 \\
\hline $\mathrm{X}$ & 286.433 & 2 & 143.217 & 3.835 & .027 & .119 \\
\hline Error & 2128.550 & 57 & 37.343 & 7 & & \\
\hline Total & 67821.000 & 60 & & & & \\
\hline Corrected Total & 2414.983 & 59 & & & & \\
\hline a. R Squared =.119 (Adjusted R Squared =.088)
\end{tabular}

Based on the table above, the result of variance analysis can be explained as follows: Ho shows that pedagogic knowledge of teachers who follow advanced training is lower than those who follow basic and other training in North Maluku province for overall is rejected because $\mathrm{Fh}>\mathrm{Ft}$, because $\mathrm{Fh}=3.835>\mathrm{Ft}(\alpha 0.05)=3.168$. This shows that the pedagogical knowledge of teachers who follow the advanced training is higher than the teachers who follow the basic training, and higher than other training. There is the effect of tiered training on pedagogical knowledge of early childhood teachers. 


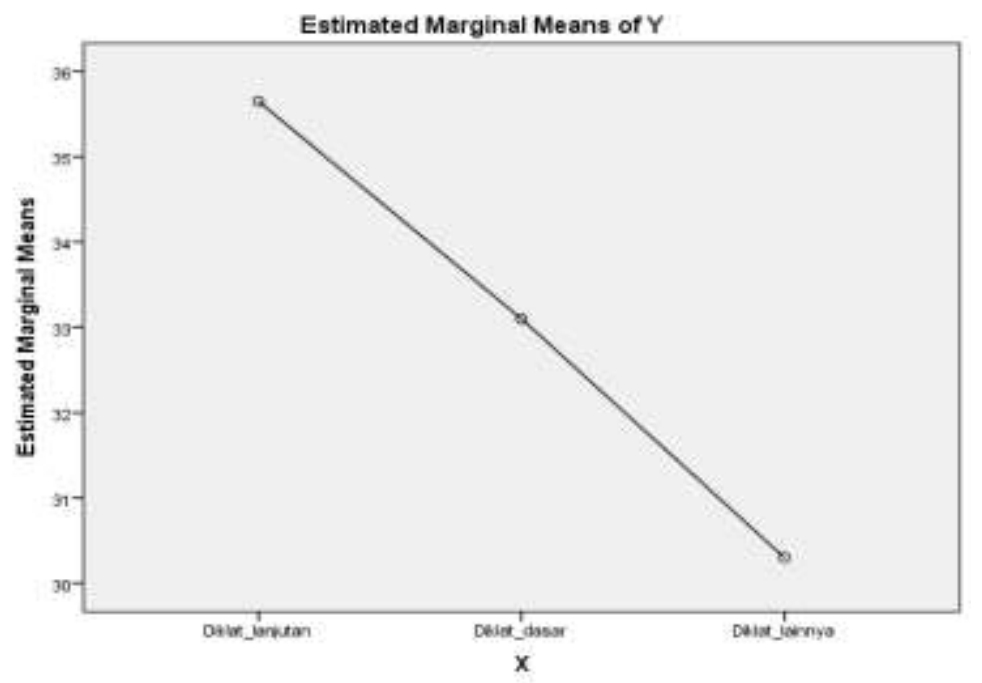

\section{Discussion:-}

Picture 1:- Visualization of interaction between tiered training on pedagogic knowledge

The result of the research on the hypothesis shows that to achieve the expected pedagogic knowledge, the use of the training offered is advanced training because the recall of training in advanced training is very helpful in the development of competence, especially in pedagogical knowledge of early childhood teachers such as the understanding of early childhood curriculum, early childhood learning strategy, child growth detection that is not found in basic training and other training which become some indicator in assessing pedagogic knowledge of teacher. As one of the benefits of training is to increase productivity, improve the quality of work and increase morale, develop skills, knowledge, understanding and new attitudes, increase knowledge to fit the performance or in accordance with work (Saleh 1992: 29).

\section{Conclusion:-}

Based on the processing, data analysis, hypothesis testing and discussion of research findings, it can be concluded as follows: There is a difference of pedagogic knowledge of teachers who are following advanced training of early childhood education, basic education and other training in North Maluku Province. Pedagogical knowledge of teachers who follow advanced training is higher than teachers who follow basic training and other training.

Some of the research findings have implications for (1) the efforts of policy makers in selecting the right type of training for teachers, (2) efforts in the selection of materials in the appropriate education for early childhood teachers in pedagogical knowledge improvement, (3) Efforts of learning strategies in the implementation of training for teachers.

\section{References:-}

1. Cochran, DeRuiterdan King. Pedagogical Knowledge (PK)", http://en.wikipedia.org/wiki/LeeShulman. (accessed on 2017)

2. Gurung A. R Ragan and Beth M. Schwartz. Optimizing Teaching and Learning, Practicing Pedagogical Research. Oxford: Wiley-Bicwell, 2009

3. Hargreaves Pat. The Human Resource Develohment Handbook. Stylus Hublishing Inc, London: 2000.

4. Kaiser David. Pedagogy and the Practice of Science. MIT Press, Massachusetts, 2005

5. Kerlinger Fred N. Foundation of Behavioral Research. USA: New York University,1973

6. Saleh Marjuki. Strategi Pelatihan dan Model Pelatihan, Malang: IKIP 1992

7. Wexley Kenneth N. and Gary A. Yuki. Organizational Behavior and Personal Psycholog. Ontario: Richard D. Irwin, Inc, 1977

8. Data Direktorat Jendral Guru dan Tenaga Kependidikan Ministry of Education and Culture Republic of Indonesia (KEMENDIKBUD). 2015. htpp://forumpendidikkristen.files.wordhress.com/2014/03/kebijakanpembinaan-ptk-paud-melalui-diklat-berjenjang.hdf. Accessed on 5 November 2016. 